\title{
A Research on the Fruitfulness of the Reddish-Yellow Acrisol in Serra da Meruoca, Ceará, Brazil
}

\author{
Marcos Venicios Ribeiro Mendes ${ }^{1}$, Simone Ferreira Diniz ${ }^{1}$, Cleire Lima da Costa Falcão ${ }^{2}$, José Falcão Sobrinho ${ }^{1}$ \\ \& Francisca Edineide Lima Barbosa ${ }^{1}$ \\ ${ }^{1}$ Vale do Acaraú State University (UVA), Ceará, Brazil \\ ${ }^{2}$ State University of Ceará (UECE), Ceará, Brazil \\ Correspondence: José Falcão Sobrinho, Professor of the Graduate Program in Geography at UVA, Ceará, Brazil. \\ E-mail: falcao.sobral@gmail.com
}

Received: January 29, $2021 \quad$ Accepted: April 18, $2021 \quad$ Online Published: April 21, 2021

doi:10.5539/jms.v11n1p168 URL: https://doi.org/10.5539/jms.v11n1p168

\begin{abstract}
Agriculture, to be successful, needs soil to have a potential nutrient composition that is relevant to plants. Therefore, it is necessary to identify the conditions for farming through soil analysis. Thus, this manuscript makes it possible to analyze the fruitfulness of two samples of the reddish-yellow acrisol—one with vegetation and the other without it - from Serra da Meruoca, a humid area in the semi-arid region of Ceará. Concerning the material and method, the stages were literature review, researches on cartographic bases, fieldwork, and data collection and their analysis in the laboratory. The results show that the area of acrisol with vegetation favors the practice of agriculture, a fact observed because of carbon (C), which is indicative of soil with intense cultivation, as well as calcium $(\mathrm{Ca})$, which appeared in a significant level, typical of arable land. In the second sample, the acrisol without vegetation, the parameters that impose restrictions on agriculture are the $\mathrm{pH}$, which contains exchangeable aluminum, indicative of high acidity that leads to a leaching process. Also, the aluminum ( $\mathrm{Al})$ at a low level reflected the need for dolomitic quicklime, for the amendment of a deficient soil. Therefore, studies on its fruitfulness are essential for farmers to reap the rewards according to the results obtained and analyzed.
\end{abstract}

Keywords: fruitfulness, soil, Meruoca

\section{Introduction}

Since the farming has been gaining space in agriculture, it requires soils that deliver proper conditions to develop crops, which must be carried out through a planning system so that it does not generate environmental impacts (Costa Falcão, 2017). However, in Brazil, most kinds do not have natural parameters to develop crops. In an attempt to understand the conditions of soils, involving high fruitfulness, as well as the intensity of cultivation, it is necessary to perform analysis.

Concerning the importance of soil analysis, Cardoso (2009) emphasizes that it is the only method that allows one to know the capacity of a specific kind of soil to supply nutrients to the plants before planting. Thus, it becomes essential for the understanding of the nutritional status, as well as the fruitfulness of an area.

Therefore, soil analyses should follow a pattern, such as the intervals that may vary depending on the intensity of fertilization, the quantities of crops planted several times in the same area, as well as the established management system. The pursuit of propitious management of soils bears in mind that soil management aims to improve the physical, chemical and biological conditions, providing maintenance as well as fertility, and guaranteeing favorable agricultural production (Silva Júnior, 2019; Motin et al., 2018)

Based on the 2017 Embrapa handbook, the types of analyses are presented and organized in physical, chemical, organic matter, mineralogical, and micromorphological. In this perspective, the choice was for discussion on fruitfulness, which is the capacity of the soil to grant nutrients to plants, besides studying the essential elements and understanding how these elements can interrelate with the plant, aiming a good development of crops. (Camargo, 2005; Rocha, 2016; Lima, 2018)

Fertility analyses also have the function of understanding some stages involving the sampling processes, passing through analysis methods until arriving at the diagnosis of the results. In conclusion, it is possible to apply in the soil the proper corrective and fertilizer recommendation (Lima, 2019; Brazão \& Silva, 2018). Thus, through the 
nutritional needs of the crops, soil correction is recommended.

Therefore, the research aims to raise data on the fruitfulness of the reddish-yellow acrisol—with and without vegetation - in Serra da Meruoca, located in the northwestern portion of Ceará.

\section{The Area and Its Environment}

The area of study is in Serra da Meruoca, located $260 \mathrm{~km}$ far from the state capital Fortaleza in the northwestern Ceará, having the BR-222 highway as the principal access. Its geographical coordinates are $3^{\circ} 32^{\prime} 30^{\prime \prime}$ latitude and $40^{\circ} 27^{\prime} 18^{\prime \prime}$ longitude WGr, and the altitude is $670 \mathrm{~m}$ (IPECE, 2017).

The municipalities bordering Meruoca are Massapê to the North, Sobral to the South, Massapê to the East, and Alcântaras to the West. Its territorial measures have as absolute area $149.8 \mathrm{~km}^{2}$ and relative area $0.10 \%$, having within its territory six districts, namely Anil, Camilos, Palestina do Norte, Santo Antônio dos Fernandes, São Francisco and Meruoca (IPECE, 2017; IBGE, 2019).

In this perspective, it is appropriate to characterize the physical environment-rock, relief, climate, soil, and vegetation - for the understanding of environmental sustainability, and the use/occupation of the area, which is different from other relief units in the northwestern region. The lithology in Serra da Meruoca is part of the Meruoca Granite group (14m), which according to 2014 CPRM studies, is intrusive in rocks. It comprises the Granja complex, the Martinópolis, and Ubajara groups, whose boundaries are the Jaibaras basin to the North and the Café-Ipueiras fault to the East.

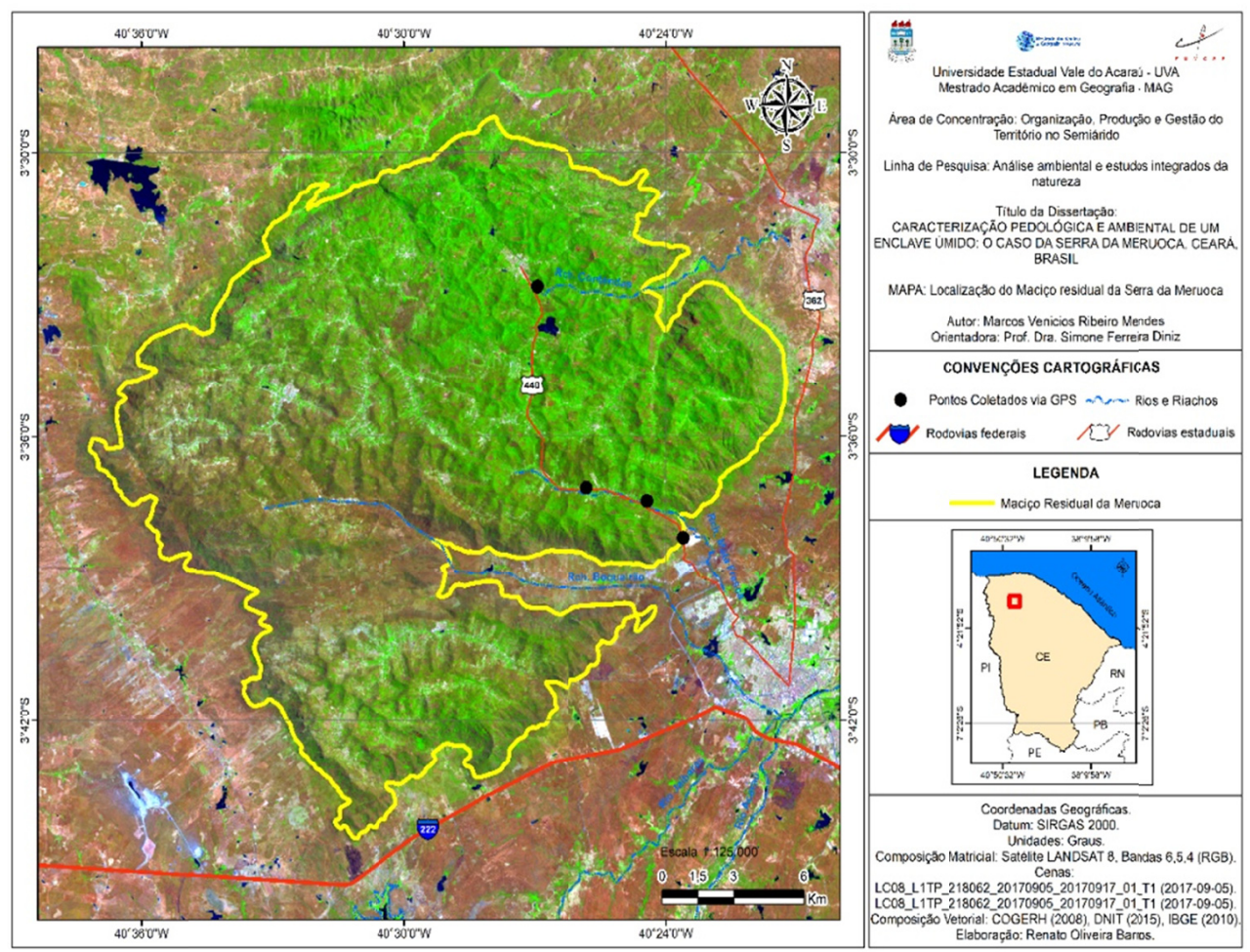

Figure 1. The area of study

From a geomorphological viewpoint, Serra da Meruoca falls into the category of residual massifs, which Ab'Sáber (1999) also refers to them as wet highlands, wetlands, and caatinga moist-forest enclaves. They occur to break the monotony of the physical and ecological aspects inserted into the reality of the dry northeastern region.

Regarding the hydroclimatic conditions, the climate is the semi-arid and sub-humid warm tropical (IPECE, 2017). The rainfall levels in the area range between 400 and $800 \mathrm{~mm}$, which is high due to the humidity from the coast that causes orographic rainfall. The high average annual temperatures vary between $27^{\circ} \mathrm{C}$ and $29^{\circ} \mathrm{C}$ because the mountain lays inside the semi-arid interplanaltic depression (Ab'Sáber, 1974).

Regarding the pedological aspect of Serra da Meruoca, it is a mosaic of soils since it presents several kinds 
identified through existing works of the area, as well as through the Empresa Brasileira de Pesquisa e Agropecuária (Brazilian Company of Research and Agriculture, Embrapa). The types identified were the reddish-yellow acrisol, luvisol, neosol of the type litholic, alluvial, and quartzarenic, according to EMBRAPA (2018).

Since the predominant soils among the abovementioned kinds are the reddish-yellow acrisol and the neosol, they deserve a short presentation regarding their characteristics. However, Embrapa (2018) expresses that the reddish-yellow acrisol contains mineral material, whose differential characteristics are the low-activity clay, and the presence of the B horizon. Concerning the agricultural practice, this type of soil presents a more significant potential for farming (Falcão Sobrinho, 2017). It is worth remembering that these soils are in the high areas of the mountain - also called as the humid plateaus.

EMBRAPA (2018) understands that neosol contain mineral or organic matter with little thickness that does not present significant changes in relation to the original material due to the low intensity of the pedogenetic processes. In reference to agricultural practice, it has restrictions caused by several factors, principally by the high susceptibility to erosion (Falcão Sobrinho, 2017).

Water erosion becomes common in this place since it occurs due to sediment drag, one of the principal causes of degradation (Sakuno, 2020). This situation is typical in areas with steep slopes, as is the case of mountain environments. Also, these kinds of soil are in the lower parts of the mountain.

In its phyto-ecological set, according to Fernandes (2006), Serra da Meruoca presents three types of vegetation, namely rainforest (evergreen), seasonal tropical forest (semideciduous) and shrubby caatinga (deciduous). It is worth mentioning that, in humid mountains, it impacts the relief the most (Moro, 2015). Besides, it is essential to minimize erosion processes, something common in that area.

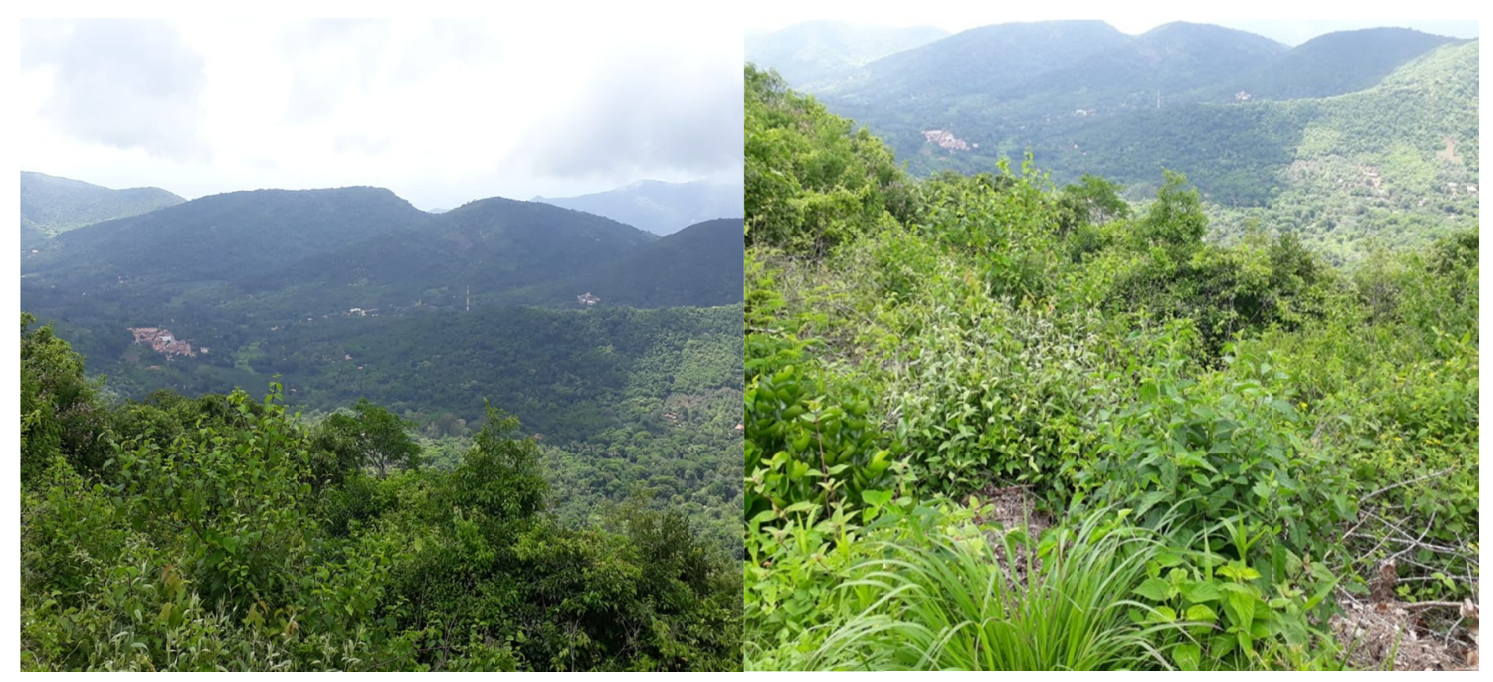

Figure 2. Serra da Meruoca Residual Massif, Ceará

\section{Material and Methods}

For methodological purposes, an investigative analysis was necessary as a basis for the development of the writing displayed here. To this end, the research had as a path, an analytical and exploratory program including the stages of literature review, surveys of cartographic bases, fieldwork, and data collection and analysis in the laboratory.

The first phase was the search for literature as a theoretical element of the research, with a focus on papers that study the subject matter addressed. The second phase was the survey of cartographic bases, which included the production of maps of the area of study.

The third phase involved fieldwork, which provided the observation and description of the physical items (geology, geomorphology, climate, soils, and vegetation), the collection of soil samples (reddish-yellow acrisol with vegetation and without it), the vegetation and proper photographic records. 
The fourth phase was the laboratory sample preparation. The material collected consisted of $1 \mathrm{~kg}$ of each sample taken from the arable layer $(60 \mathrm{~cm})$ and then taken to the soil laboratory from the Instituto Federal de Educação, Ciência e Tecnologia (Federal Institute of Education, Science, and Technology of Ceará, IFCE) in Sobral. The chemical analysis (fertility) took place according to the recommendations of the soil analysis method handbook, proposed by (EMBRAPA, 2017).

Therefore, the two areas selected for the sample collection are the areas I and II, respectively. Thus, the distribution of those areas happened as follow:

\section{Area I-(Reddish-yellow acrisol with vegetation)}

Its coordinates are $03^{\circ} 32^{\prime} 811^{\prime \prime}$ South latitude and $040^{\circ} 27^{\prime} 058^{\prime \prime}$ West longitude, and its altitude is $697 \mathrm{~m}$.

\section{Area II-(Reddish-yellow acrisol without vegetation)}

Its coordinates are $03^{\circ} 32825^{\prime}$ South latitude and $040^{\circ} 27.014$ " West longitude, and its altitude is $670 \mathrm{~m}$.

Arruda (2014) highlights that the preparation method of a sample is essential for the rational, sustainable, and economic use of soils. It happens through a proper recommendation of fertilizer and corrective products, which will be responsible for a considerable part of the productivity of a crop. Besides, Rocha (2016) reveals that before the collection, it is necessary to establish the objectives because the sampling is different when it is the first time in an area.

\section{The chemical parameters (fertility) happened this way:}

The $\mathrm{pH}$ measuring happened through a combined electrode immersed in soil suspension, liquid (water, $\mathrm{KCl}$, or $\mathrm{CaCl}^{2}$ ) in ratio $1: 2.5$. The electrical conductivity of this solution was approximately $2.3 \mathrm{mS} / \mathrm{cm}$. Regarding interchangeable cations $\left(\mathrm{Ca}^{2+}, \mathrm{Mg}^{2+}, \mathrm{Na}^{+}\right)$, the extracting solution employed- $\mathrm{KCl} 1 \mathrm{~mol} / \mathrm{L}$ method at $\mathrm{pH}$ 7 - demonstrated calcium and magnesium by standardized EDTA. Through the photometers, the calibration read the levels of sodium and potassium. The hydrogen and aluminum, extracted and calculated in samples with $\mathrm{pH}$ below 7.0, used calcium acetate $0.5 \mathrm{~mol} / \mathrm{L}$.

Concerning carbon, its generation took place through the oxidation of soil organic matter, oxidized with a mixture of potassium dichromate, involving concentrated sulphuric acid. In these conditions, the collection happened through the Mehlich-1 solution in the flame photometer. The T value, which is the total of negative charges that the soil can adsorb, was determined by the sum of the $\mathrm{S}$ value and the potential acidity $\left(\mathrm{H}^{+}+\mathrm{Al}^{3+}\right)$. The acquisition of the $\mathrm{V}$ or $\mathrm{V} \%$ value, which indicates the proportion of the CTC of the soil by filling itself with exchangeable bases, was in the ratio of the sum of the base and the capacity of the cation exchanges with $\mathrm{pH} 7.0$, being expressed by the formula $\mathrm{V}=\mathrm{S} / \mathrm{Tx} 100$ (EMBRAPA, 2017).

\section{Results and Discussion}

Based on the literature review, fieldwork, soil sample collection, and data analysis, it was possible to analyze the fruitfulness of the reddish-yellow acrisol with the presence of vegetation and without it. The chemical parameters analyzed are as follows carbon, organic matter, $\mathrm{pH}$, phosphorus, calcium, magnesium, sodium, aluminum. Below is the table with the results extracted in the laboratory.

It is important to emphasize that it is relevant to describe each chemical element (fertility) presenting its characteristics for soil analysis, namely:

Table 1. Chemical analysis of soils (fertility)

\begin{tabular}{|c|c|c|c|c|c|c|c|c|c|c|c|c|c|c|c|c|}
\hline Depth & C & $\begin{array}{l}\text { MO } \\
\mathrm{g} / \mathrm{kg}\end{array}$ & pH & $\begin{array}{l}\mathbf{P} \\
\mathrm{mg} / \mathrm{kg}\end{array}$ & $\mathbf{K}$ & $\begin{array}{l}\text { Ca } \\
\mathrm{cmolc} / \mathrm{kg}\end{array}$ & Mg & $\mathbf{N a}$ & $\mathbf{A L}$ & $\begin{array}{l}\mathbf{H}+\mathbf{A L} \\
\mathrm{cmolc} / \mathrm{kg}\end{array}$ & SB & CTC & $\mathbf{V}$ & $\begin{array}{l}\text { PST } \\
\%\end{array}$ & $\mathbf{m}$ & $\begin{array}{l}\mathbf{C E} \\
\mathrm{dS} / \mathrm{m}\end{array}$ \\
\hline \multicolumn{17}{|c|}{ Acrisol with Vegetation } \\
\hline $\begin{array}{l}0.60 \\
\mathrm{~cm}\end{array}$ & 5.33 & 9.19 & 6.1 & 0.91 & 0.102 & 4.7 & 1.6 & 0.391 & 0.05 & 0.5 & 6.79 & 7.29 & 93.21 & 5.37 & 0.73 & 0.33 \\
\hline \multicolumn{17}{|c|}{ Acrisol without Vegetation } \\
\hline $\begin{array}{l}0.60 \\
\mathrm{~cm}\end{array}$ & 4.13 & 7.12 & 4.9 & 1.12 & 0.128 & 1.00 & 1.60 & 0.261 & 0.60 & 2.15 & 2.99 & 5.13 & 58.22 & 5.08 & 16.72 & 0.09 \\
\hline
\end{tabular}

Source: IFCE 2019. 
Soil organic matter (SOM) is commonly heterogeneous and consists of animals and plants remain, that is, residues in a specific environment (Fontana, 2017). Thus, organic matter is an essential source of nutrients for plants. According to Van Raij and Battaglia (1991, p. 82), the organic matter present in the soil reflects the balance between the losses and gains that exist in each case, being factors influencing the vegetation coverage, soil texture, management, drainage, acidity, and other elements. It is worth remembering that the organic matter is heterogeneous and composed of animal remains.

Soils, when placed for agricultural use, end up suffering a decrease in organic matter content, reaching the lowest content. It portrays new conditions for the balance of oxidized organic matter and the one added to the system by the remains of decomposed organics (Van Raij \& Battaglia, 1991, p. 82).

Besides influencing the survival and production of plants, $\mathrm{pH}$ also impacts the physical, chemical, and biological components. In the soil, it points to the active acidity, which is common, and there is the suspension of the soil in water (Van Raij \& Bataglia, 1991, p. 87). Mehlich (1948) highlights that the pH is one of the simplest measures made in the soil, however, very important, reflecting in a set of complexity focused on the reactions in the system involving soil and solution. It is useful when related to the properties that compose the soil.

Moreira (2006, p. 7) defines the phosphorus adsorption as the phenomenon in which soluble forms become weaker or even insoluble when they come into contact with the solid phase of the soil. From a different point of view, the phosphorus forms compounds that present low solubility in soils, linked in various combinations to chemical elements such as aluminum, iron, organic matter, among others (Van Raij \& Bataglia, 1991, p. 84).

Potassium $(\mathrm{K})$ is one of the elements knows as soil base along with magnesium and sodium. The reason for this is because it has an alkaline content (Van Raij \& Bataglia, 1991, p. 85). Furthermore, Diniz (2001) stresses that the amount of water in the soil becomes essential for the availability of potassium for the roots, an element taken directly from the land. It means that the water interferes with the diffusion of potassium and controls $\mathrm{Ca}^{2+}$ as well as $\mathrm{Mg}^{2+}$.

Calcium (Ca) provides the reduction of acidity in the soil and also influences the improvement of plant roots since plants with high calcium contents are resistant to the toxicity of these elements (Aquino, 2000, p. 135). Magnesium $(\mathrm{Mg})$ is a cationic and secondary macronutrient that has relevance to the development of plants.

Magnesium (M) is present in both exchangeable and non-exchangeable ways, and in soil solution, found many times in younger soils, in primary minerals $\left(\mathrm{Ca}^{2+}\right.$ and $\left.\mathrm{Mg}^{2+}\right)$. Thus, according to Aquino (2000), magnesium is part of chlorophyll and is an enzymatic activator, that is, more than half of the magnesium is fixed in the leaves, thus forming chlorophyll.

Sodium (Na) is beneficial when it comes to growth. So, its benefits are significant where there are problems filling potassium (Aquino, 2000). Aluminum (Al) is a constituent of the clay particles of the soil and in the solution, but it can cause a series of problems concerning the development of the plants when absorbed.

Miguel (2010) points out that one of the symptoms presented by aluminum in plant growth is the root reduction, considered sensitive, thus occurring the difficulty for plants to absorb water, as well as its nutrients deep in their surface rooting.

Therefore, $\mathrm{H}+\mathrm{Al}$ is the hydrogen content associated with aluminum in the soil, whose function is to determine the potential acidity, as well as the exchangeable acidity, where the hydrogen content or non-exchangeable acidity is the difference between $\mathrm{H}+\mathrm{Al}$ and $\mathrm{Al}^{3^{+}}$. The neutral solution of calcium acetate absorbs the potential acidity (Van Raij \& Bataglia, 1991, p. 86).

However, the sum of bases (SB) is the representation of the summation of the interchangeable cations contents, except $\mathrm{H}^{+}$and $\mathrm{Al}^{3^{+}}\left(\mathrm{SB}=\mathrm{Ca}^{2+}+\mathrm{Mg}^{2+}+\mathrm{K}^{+}\right.$) (EMBRAPA, 2017). Base saturation is a more viable indicator for general indications of soil fertility, used as an additive in soil nomenclature (EMBRAPA, 2017).

The cation exchange capacity (CEC) is the number of negative charges a soil has. So, if much of the CEC has essential cations, such as $\mathrm{Ca}^{2+}, \mathrm{Mg}^{2+}$ and $\mathrm{K}^{+}$, then the soil is adequate for plant nutrition (Roquin, 2010).

Base saturation $(\mathrm{V} \%)$ is for the recommendations of the need for liming, as well as fertilizers. They improve the fertility of the soil so that the plants can find the nutrients they need to achieve high yields (Roquin, 2010).

The exchangeable sodium percentage (ESP) is a relevant parameter in determining the ability of a soil to expand and contract. In these conditions, it demonstrates the ratio of sodium to other adsorbed cations.

The percentage of saturation per aluminum $(\mathrm{m} \%)$ demonstrates the fraction or even the percentage of the effective CEC of the interchangeable acidity or Al. Thus, Lopes and Guilherme (2004, p. 10) point out that the more acid the soil, the higher can be the exchangeable aluminum content, the higher the saturation percentage 
per $\mathrm{Al}$, the lower the $\mathrm{Ca}, \mathrm{Mg}, \mathrm{K}$ contents and, consequently, the lower the sum of exchangeable bases. In other words, it is another way to expose the toxicity of aluminum.

Electrical conductivity (EC) is a measure of the electrical conduction path, and its measuring is through the analysis of the saturation extract. Thus, Richards (1954) mentions that the electrical conductivity of the soil is associated with water.

\section{Sample I-Acrisol with vegetation}

The carbon value of $5.33 \mathrm{~g} / \mathrm{kg}$ reflects the intense cultivation in the soil, where this concentration is due to the use of limestone and fertilizers in several crops, such as vegetables, that is, the simple superphosphate. Therefore, being the reason for the high $\mathrm{Ca}$ content, there are reports of the use of products such as nitrogen fertilizers, which creates soluble salts - the calcium nitrate present in the samples.

The value of organic matter extracted from the sample was $9.19 \mathrm{~g} / \mathrm{kg}$, typical of the Atlantic forest remnants, which provides a permanent addition of the material so that the decomposition occurs. Thus, Aquino (2000) reveals that the presence of organic matter on the soils presents a better-concentrated distribution on the surface, a fact explained by nature and way of deposition of residues. So, the organic matter is an essential source of nutrients to the plants.

The $\mathrm{pH}$ in this analysis reached 6.1, meaning that it is between 5.0 and 6.5, with characteristics of well-drained soils with high to medium acidity and favorable for corn culture. Rossa (2006) declares that this soil is in the category of cultivated soils, where the $\mathrm{pH}$ varies from 6.0 to 6.5 .

Regarding the phosphorus element, the analysis presented a value of $0.91 \mathrm{~g} / \mathrm{kg}$, considered low because since it is in a closed-forest environment, providing acid soils. Potassium is one of the elements often called soil bases along with potassium, and sodium. The value extracted from the potassium was $0.102 \mathrm{mg} / \mathrm{kg}$, considered with average content concerning the analyzed sample.

The high value extracted of calcium was $4.70 \mathrm{mg} / \mathrm{kg}$, an indication of arable soils. Magnesium is a cationic and secondary macronutrient that has relevance for the development of plants. The displayed value of the analysis was $1.60 \mathrm{mg} / \mathrm{kg}$, considered low.

Sodium is an element beneficial for growth. In these conditions, sodium is a substitute for potassium, developing functions aimed at plant nutrition (Mendes, 2007, p. 60). The value of sodium in the analysis was $0.391 \mathrm{cmol} / \mathrm{kg}$. The aluminum parameter in the sample presented a value of $0.05 \mathrm{cmol} / \mathrm{kg}$, which means low saturation and lower acidity. It is a productive soil, as long as it is applied medium to high handling.

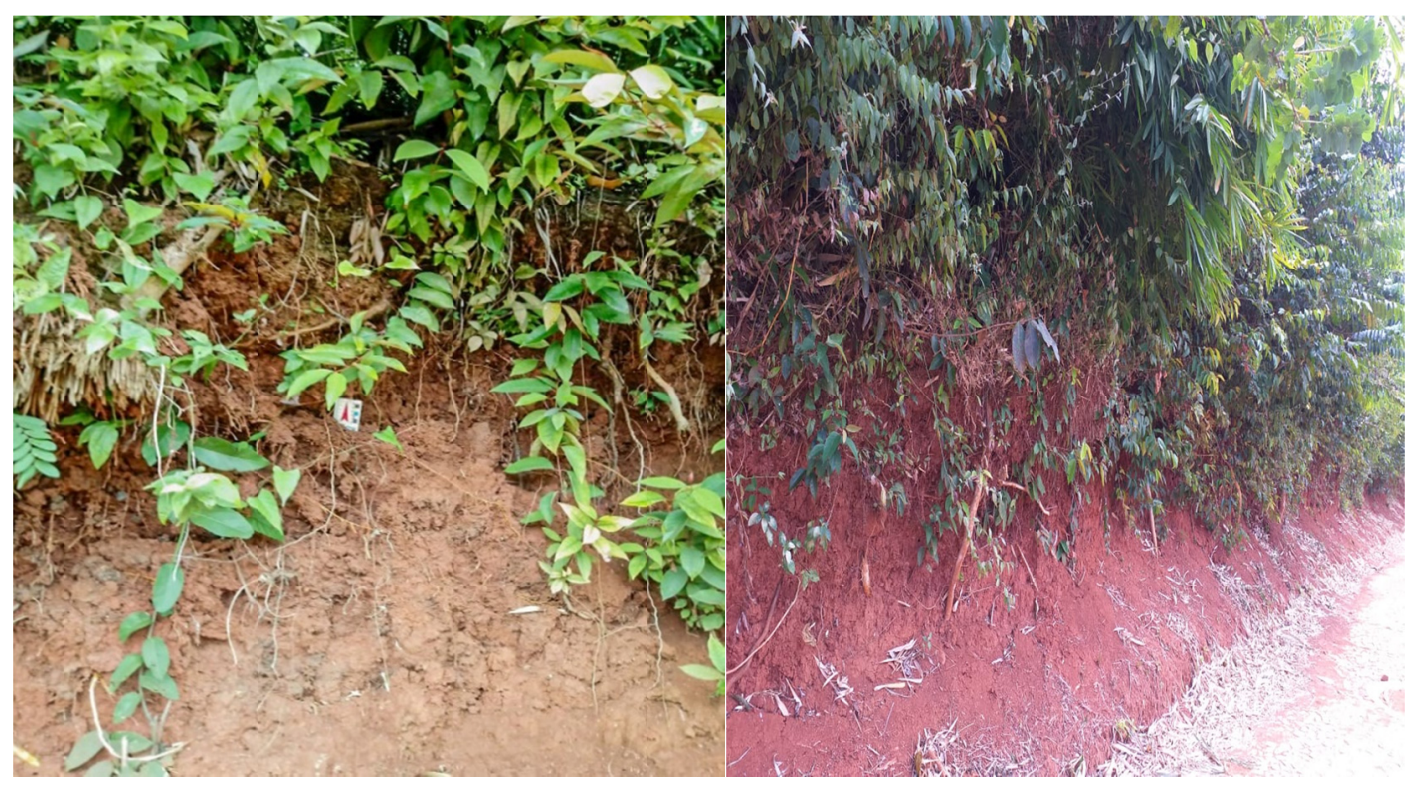

Figure 3. Acrisol with vegetation 


\section{Sample II-Acrisol without vegetation}

The sample presented a value of $4.13 \mathrm{~g} / \mathrm{kg}$ for the carbon element, indicative of the environment not frequently used for agricultural practice, no matter how productive this soil class is when compared to others.

The organic matter value was $7.12 \mathrm{~g} / \mathrm{kg}$, which is low, considering that the low levels vary from 0 to $15 \mathrm{~g} / \mathrm{kg}$. In this case, the absence of vegetation reveals this low level, presenting high susceptibility to erosion and altering the landscapes. It is often necessary for intensive measures to control erosion caused by agriculture.

The $\mathrm{pH}$ value was $4.9 \mathrm{~g} / \mathrm{kg}$, revealing acidity due to the presence of exchangeable aluminum, which leads to a leaching process. In this sense, Barbosa (2008) reports that the soils in humid areas are prone to base leaching during their evolution, making them quite acidic. However, it is necessary to apply alkaline correctives, such as dolomitic quicklime, to neutralize the acid action.

Regarding the phosphorus element in the acrisol sample, the value was $1.12 \mathrm{~g} / \mathrm{kg}$, indicating that the soil has high adsorption capacity. The potassium value was $0.128 \mathrm{mg} / \mathrm{kg}$, considered average, and may indicate weathered soil. The calcium element showed a value of $1.00 \mathrm{cmol} / \mathrm{kg}$, which indicates a low content, can be elevated with the use of dolomitic quicklime.

The magnesium was $1.60 \mathrm{mg} / \mathrm{kg}$, presenting a low value. The sodium was $0.261 \mathrm{cmol} / \mathrm{kg}$, indicating that this soil suffered from the weathering process. Regarding the aluminum parameter, it was $0.60 \mathrm{cmol} / \mathrm{kg}$, which by being low, is advisable the use of dolomitic quicklime correct the acidity.

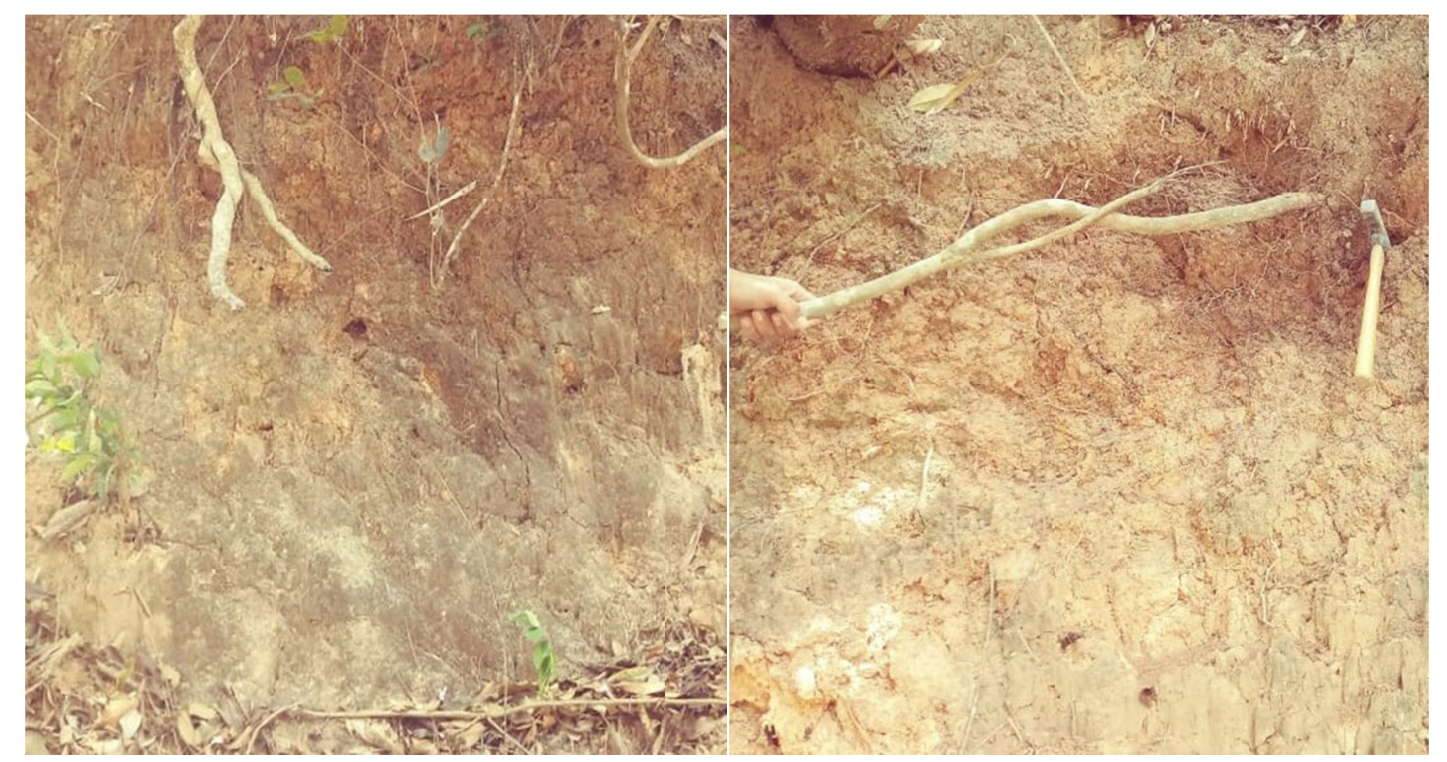

Figure 4. Acrisol without vegetation

\section{Final Considerations}

Serra da Meruoca presents a diversity of soils, delivering a good agricultural performance. For a good development of agriculture, the soils must present characteristics that favor specific crops. Therefore, it is necessary to analyze them-whether physical or chemical - to understand if they are recommendable for agriculture. The chemical analysis considered areas I and II, containing reddish-yellow acrisol with vegetation and without it, respectively.

Through data obtained in the laboratory, the Area I — reddish-yellow acrisol with vegetation-delivers a good soil for agriculture, and has been contributing to maintaining the potentiality of the area. It is due to the chemical element carbon (C), which reflects in soils of excess cultivation, as well as the element $(\mathrm{Ca})$, which is another indication of cultivable soils.

In Area II-reddish-yellow acrisol without vegetation - is an area that needs soil correction to obtain a greater agricultural production. For this, dolomitic quicklime is a good corrective for soils that present deficiencies, being possible to observe through the elements $(\mathrm{pH})$, which points to a process of apparent leaching, as well as the element (Al). Studies on soil fertility are relevant for farmers to achieve good results in their crops. 


\section{References}

Ab’Sáber, A. N. (1974). Domínio Morfoclimático Semiárido das Caatingas Brasileiras. Geomorfologia, n. 43 IG- USP. São Paulo.

Ab'Sáber, A. N. (1999). Sertões e Sertanejos: uma geografia humana sofrida. Revistas Estudos Avançados, 13(36), 7-59. https://doi.org/10.1590/S0103-40141999000200002

Aquino, B. F. (2000). Conceitos fundamentais em fertilidade do solo (p. 181). Fortaleza.

Arruda, M. R., Moreira, A., \& Pereira, J. C. R. (2014). Amostragem e Cuidados na Coleta de Solo para Fins de Fertilidade. Embrapa Amazônia Ocidental Manaus, AM.

Barbosa, W. R. (2008). Evolução Pedogenética em Duas Vertentes do Maciço de Baturité - CE. Dissertação de Mestrado UFC, Fortaleza.

Cardoso, L. E., Fernandes, M. B. A. H., \& Fernandes, A, F. (2009). Análise de Solos: Finalidade e Procedimentos de Amostragem. Corumbá, MS.

Carmagos, S. L. (2005). Conceitos sobre Fertilidade e Produtividade (pp. 1-41). Cuiabá - MT.

Costa Falcão, C, L. (2017). Erosão Hídrica do solo e a Estimativa da Produção de Sedimentos, em uma Área de Maciço Residual Úmido no Semiárido Cearense (pp. 6372-6380). XVII Simpósio Brasileiro de Geografia Física Aplicada I congresso Nacional de Geografia Física. Os Desafios de Geografia Física na Fronteira do Conhecimento. Instituto de Geociências- Unicamp, Campinas-SP 28 de Junho a 02 de Julho de. https://doi.org/10.20396/sbgfa.v1i2017.2529

CPRM. (2014). Serviço Geológico do Brasil. Ministério de Minas de Energia. Mapa Geológico do Ceará, 1:100.000 CPRM.

Diniz, S. F. (2001). Fontes de potássio não trocável e potássio total em solos do estado do Ceará. Dissertação (mestrado em solos) - Universidade Federal do Ceará, Fortaleza, Ceará.

EMBRAPA. (2017). Manual de métodos de análise de solo (Paulo César Teixeira et al., 3rd ed.). Brasília, DF: Embrapa.

EMBRAPA. (2018). Centro Nacional de Pesquisas de Solos. Sistema Brasileiro de Classificação de Solos (5th ed.). Brasília -BR.

Falcão Sobrinho, J., Costa Falcão, C. L., Mendes, M. V. R., \& Paiva, A. M. (2017). Integração dos Elementos Geomorfológicos e Pedológicos em Boqueirão (Sobral, CE, pp. 71-77). XVII Simpósio Brasileiro de Geografia Física Aplicada I Congresso Nacional de Geografia Física. Os Desafios de Geografia Física na Fronteira do Conhecimento. Instituto de Geociências - Unicamp, Campinas-SP. https://doi.org/10.20396/sbgfa.v1i2017.2319

Fernandes, A. (2016). Fitogeografia Brasileira. Fortaleza: Realce, 2006. In: LIMA, J.S. Proposta de zoneamento geoambiental para a área de proteção ambiental serra da Meruoca, Ceará 2016. 166 f. Dissertação (Mestrado em Geografia) - Universidade Estadual do Ceará, Centro de Ciências e Tecnologia, Programa de Pós Graduação em Geografia, Fortaleza.

Fontana, A. (2017). Solos com Altos Teores de Matéria Orgânica. In EMBRAPA (Ed.), Manual de Métodos de Análise de Solo (Paulo César Teixeira et al., 3rd ed.). Brasília, DF: Embrapa.

IBGE. (2019). Município de Meruoca - Ceará. Rio de Janeiro.

IPECE. (2017). Instituto de Pesquisa e Estratégia Econômica do Ceará. Fortaleza.

Lima, J. S. (2016). Proposta de zoneamento geoambiental para a área de proteção ambiental serra da Meruoca, Ceará. 166 f. Dissertação (Mestrado em Geografia) - Universidade Estadual do Ceará, Centro de Ciências e Tecnologia, Programa de Pós Graduação em Geografia, Fortaleza.

Lima, J. S. S. et al. (2018). Fuzzy logic and geostatistics in studying the fertility of soil cultivated with the rubber tree. Revista Ciência Agronômica, 49(2), 228-238, abr-jun, 2018 Centro de Ciências Agrárias Universidade Federal do Ceará, Fortaleza, CE. https://doi.org/10.5935/1806-6690.20180026

Lima, T. M. (2019). Diagnóstico da fertilidade do solo e do nível tecnológico de propriedades rurais no Triângulo Mineiro e Alto Paranaíba. 2019. 138 f. Tese (Doutorado em Agronomia) - Universidade Federal de Uberlândia, Uberlândia.

Lopes, A. S., \& Guilherme, L. R. G. (2004). Interpretação de análise de solo. conceitos e aplicações (2nd ed., p. 
50). Boletim técnico. São Paulo, Associação Nacional de Difusão de Adubos.

Mehlich, A. (1948). Determination of Cation and Anion Exchange Properties of Soils. Soil Sci., 66, 429-446. https://doi.org/10.1097/00010694-194812000-00004

Mendes, A. M. S. (2007). Introdução a fertilidade do solo. In curso de manejo e conservação do solo e da água. Barreiras. Palestras: Mapa; SFA-BA: Embrapa Semiárido; Embrapa Solos-UEP Recife, 2007. CD-ROM.

Miguel. P. S. B. et al. (2010). Efeitos tóxicos do alumínio no crescimento das plantas: mecanismos de tolerância, sintomas, efeitos fisiológicos, bioquímicos e controles genéticos. CES Revista, 24, 1-20, Juiz de Fora.

Moreira, F. L. M. et al. (2006). Adsorção de fósforo em solos do Estado do Ceará. Revista Ciência Agronômica, $37(1), 7-12$.

Moro, M. F. et al. (2015). Vegetação, unidades fitoecológicas e diversidade paisagística do estado do Ceará. Rodriguésia. Revista do jardim botânico do Rio de Janeiro, 66(3), 717-743. https://doi.org/10.1590/2175-7860201566305

Motin, M. C., Anschau, K. A., \& Seidel, E. P. (2018). Cultivo de plantas de cobertura no inverno: produtividade de massa seca e cobertura do solo. In Elementos da natureza e propriedades do solo (Vol. 6 recurso eletrônico). Organizadores. Fábio Steiner, Alan Mario Zuffo. Ponta Grossa (PR): Atena Editora.

Richards, L. A. (1954). Diagnosis and improvement of saline and alkali soils (p. 160). Washington: U.S. Salinity Laboratory Staff, USDA. (Agriculture Handbook, 60).

Rocha, J. L. (2016). An interpretação da análise de solo e recomendação de adubação: princípios e perspectivas. POMBAL (PB).

Roquin, C, C. (2010). Conceitos de fertilidade do solo e manejo adequado para as regiões tropicais. Embrapa Monitoramento por Satélite Campinas, SP.

Rossa, U, B. (2006). Estimativa de calagem pelo método smp para alguns solos do paraná. Dissertação de mestrado, Universidade Federal do Paraná, Curitiba.

Sakuno, N. R. R. et al. (2020). Adaptation and application of the erosion potential method for tropical soils. Revista Ciência Agronômica, 51(1), e20186545, 2020 Centro de Ciências Agrárias - Universidade Federal do Ceará, Fortaleza, CE. https://doi.org/10.5935/1806-6690.20200004

Silva J. J. (2019). Matéria orgânica do solo em sistemas de produção agrícola e cerrado do oeste baiano. Doutorado em Agronomia, Universidade Federal de Uberlândia, Uberlândia.

Silva, S, B. (2018). Amostragem para avaliação da fertilidade do solo. In Análise de solos para ciências agrárias (2nd ed., p. 174). Belém: EDUFRA.

Van Raij, B., \& Bataglia, O. C. (1991). Análise de Laboratório. In A. J. de, Oliveira, W. E. GARRIDO, J. D. de, ARAUJO \& LOURENÇO (Eds.), Métodos de pesquisa em fertilidade do solo. Brasília, Instituto Agronômico.

\section{Copyrights}

Copyright for this article is retained by the author, with first publication rights granted to the journal.

This is an open-access article distributed under the terms and conditions of the Creative Commons Attribution license (http://creativecommons.org/licenses/by/4.0/). 